\title{
ANALISIS PENILAIAN AHLI TERHADAP PROTOTIPE BAHAN AJAR CERITA DONGENG BERWAWASAN NILAI KARAKTER
}

\section{ANALYSIS OF EXPERTS' JUDGMENT ON MATERIAL PROTOTYPE OF FAIRY TALE OF CHARACTER VALUES INSIGHT}

\author{
Cicilia Clara Devi Anggraini ${ }^{1 a}$ \\ Jurusan Pendidikan Guru Sekolah Dasar, Fakultas Ilmu Pendidikan dan Keguruan \\ Universitas Terbuka, Jl. Pondok Cabe Raya, Tangerang Selatan \\ Korespondensi: telp. 085700927765 email: cicilia.anggraini@ecampus.ut.ac.id
}

\begin{abstract}
This research aims to analyze the expert judgment of teaching materials prototype of fairy tale storytelling are the insight of character values. Expert validation of the prototype of fairy tale storytelling with character values aims to obtain inputs, suggestions, opinions, comments as material improvement and refinement before trial. Expert consultation is done in 3 stages, namely: (1) conveying the concept of prototype compiled and enclosed with the validation sheet; (2) accept the results of good reviews in the form of comments, feedback, and suggestions for improvement; and (3) deliver prototypes based on review results submitted to experts to obtain expert approval. Expert validation is performed by three experts namely media expert validation, material expert validation and validation of linguists. Data collection techniques in this research are in the form of a questionnaire by using an in-depth interview method (in-depth interview). Test the validity of data is using Sugiyono data collection conducted through in-depth interviews (in-depth interviews) and Aiken validation. The results of this study indicate that: (1) validation of material experts requested to assess the feasibility of the material is Prof. St. Y. Slamet, M.Pd, a professor at Sebelas Maret University and Dwi Sulistyowati, M.Pd a senior teacher and principal in SD Negeri 6 Purwodadi Grobogan Regency resulted in a worthy teaching material tested with revisions as per suggestion; (2) validation of media experts who are ask to judge the appearance in the subject of fairy tales is insight of characteristic values is Lecturer of Sebelas Maret University Dr. Roemintoyo, M.Pd and NurBadriah, M.Teach a senior elementary school teacher in SD Negeri 3 Ngraji, Grobogan Regency resulted in a worthy teaching material tested with revisions as suggestion; (3) the validation of the linguist who is ask to assess the feasibility of the language used in the teaching of fairy tales with the insight of character values is Dr. Rukayah, M. Hum and D Sri Wahyuni, M.Pd; a senior teacher and headmaster at SD Negeri 2 Ngembak of Grobogan Regency result is a worthy teaching material to be tested with revisions as suggestion.
\end{abstract}

Keywords: expert judgment; teaching materials, fairy tale; character values.

Abstrak

Penelitian ini bertujuan untuk menganalisis penilaian ahli terhadap prototype bahan ajar cerita dongeng berwawasan nilai-nilai karakter. Validasi pakar terhadap prototype ajar cerita dongeng berwawasan nilai-nilai karakter bertujuan memperoleh masukan, saran, pendapat, komentar sebagai bahan perbaikan dan penyempurnaan sebelum diujicobakan. Konsultasi dengan pakar dilakukan dalam 3 tahap, yakni: (1) menyampaikan konsep prototype yang disusun dan dilampiri lembar validasi; (2) menerima hasil review baik yang berupa komentar, masukan, dan saran untuk perbaikan; dan (3) menyampaikan prototype berdasarkan hasil review yang disampaikan ke pakar untuk memperoleh persetujuan pakar. Validasi ahli dilakukan oleh tiga orang ahli yaitu validasi ahli media, validasi ahli materi dan validasi ahli bahasa. Teknik pengumpulan data dalam penelitian ini berupa angket dengan menggunakan metode wawancara mendalam (in depth interview). Uji validitas data menggunakan pengumpulan data Sugiyono yang dilakukan melaluiwawancara mendalam (in depth interview) dan validitas aiken. Hasil penelitian ini menunjukkan bahwa: (1) validasi ahli materi yang diminta menilai kelayakan materi adalah Prof. St. Y. Slamet, M.Pd seorang guru besar di Universitas Negeri Sebelas Maret dan Dwi Sulistyowati, M.Pd seorang guru senior dan kepala sekolah di SD Negeri 6 Purwodadi 
Kabupaten Grobogan hasilnya adalah bahan ajar layak diujicobakan dengan revisi sesuai saran; (2) validasi ahli media yang diminta untuk menilai tampilan dalam bahan ajar cerita dongeng berwawasan nilai-nilai karakter adalah Dosen Universitas Negeri Sebelas Maret Dr. Roemintoyo, M.Pd dan Nur Badriah, M.Teach seorang guru sekolah dasar senior di SD Negeri 3 Ngraji, Kabupaten Grobogan hasilnya adalah bahan ajar layak diujicobakan dengan revisi sesuai saran; (3) validasi ahli bahasa yang dimintai menilai kelayakan bahasa yang digunakan dalam bahan ajar cerita dongeng berwawasan nilainilai karakter adalah Dr. Rukayah, M.Hum dan D Sri Wahyuni, M.Pd; seorang guru senior dan kepala sekolah di SD Negeri 2 Ngembak Kabupaten Grobogan hasilnya adalah bahan ajar layak diujicobakan dengan revisi sesuai saran.

Kata kunci: penilaian ahli; bahan ajar, cerita dongeng; nilai-nilai karakter.

Anggraini, C.C.D. (2019). Analisis Penilaian Ahli Terhadap Prototipe Bahan Ajar Cerita Dongeng

Berwawasan Nilai Karakter. Didaktika Tauhidi: Jurnal Pendidikan Guru Sekolah Dasar, 6(2), 113129

\section{PENDAHULUAN}

Berbagai upaya telah dilakukan untuk meningkatkan perbaikan mutu pendidikan di Indonesia melalui berbagai pelatihan peningkatan kompetensi guru, pengadaan buku dan alat pelajaran, perbaikan sarana dan prasarana pendidikan, peningkatan mutu manajemen sekolah, serta peningkatan kualitas tenaga pengajar. Salah satunya upaya untuk peningkatan kualitas pendidikan melalui Bahan ajar tersebut diharapkan membawa dampak positif terhadap pendidikan di Indonesia khususnya pada mata pelajaran Bahasa Indonesia.

Bahan ajar menjadi penghubung antara guru dan siswa saat ini berperan sebagai fasilitator, sehingga penggunaan bahan ajar dapat menjembatani permasalahan keterbatasan daya serap siswa dan kemampuan guru dalam mengelola pembelajaran di kelas. Menurut (Daryanto, 2014, p. 171), "Bahan ajar adalah segala bentuk bahan yang digunakan untuk membantu guru/instruktor dalam melaksanakan kegiatan belajar mengajar di kelas, bahan yang dimaksud bisa berupa bahan tertulis maupun bahan tidak tertulis". Dalam analisis bahan ajar ini adalah cerita dongeng.

"Mendongeng adalah salah satu metode yang sangat baik untuk meningkatkan kecerdasan anak". Untuk meningkatkan kecerdasanan aku unsure keterampilan membaca intensif sangatlah penting diperhatikan untuk pengembangan bahan ajar cerita dongeng. Pendapat tersebut di dukung dengan penelitian (Febriani, 2012,p. 2) mengatakan bahwa "Dongeng digunakan sebagai metode untuk memperoleh informasi yang merupakan kekayaan budaya bangsa ini, sebelum era masyarakat mengenal tulisan, dongeng merupakan media penanaman nilainilai sosial yang adiluhung oleh para orangtua dan nenek moyang ke generasi penerus.”Nilai-nilai sosial yang dimaksud 
adalah nilai-nilai yang terkandung dalam cerita dongeng.

/Menurut (Mustari, 2014, p.8), "Nilai-nilai karakter merupakan usaha pendidikan karakter yang dapat meningkatkan mutu karakter generasi sekarang dan yang akan datang”. Adapun nilai-nilai karakter yang dikembangkan dalam pengembangan bahan ajar cerita dongeng untuk mengembangkan keterampilan membaca intensif sebagai data pendukung telah diukur dengan menggunakan indicator dalam 10 nilai-nilai karakter yaitu indicator karakter religius, jujur, disiplin, kerja keras, mandiri, kreatif, bersahabat/komunikatif, cinta damai, peduli, dan tanggung jawab. Maka sangat penting untuk mengimplementasikan nilai-nilai karakter dalam pembelajaran salah satunya melalui penegembangan bahan ajar cerita dongeng berwawasan nilai-nilai karakter. Hal ini diperkuat dengan penelitian pengembangan yang telah dilakukan oleh (Ulum, 2014, p.131) mengatakan bahwa pendidikan kepribadian/karakter penting dilaksanakan untuk membekali peserta didik hidup mandiri.

Penelitian pengembangan yang telah dilakukan oleh (Mardiah, dkk, 2016, p. 1115) yang berjudul "Pengembangan Modul Membaca Intensif Materi Cerita Petualangan Berbasis Intensif" mengatakan bahwa membaca merupakan proses seseorang dalam merekonstruksi sebuah pesan Keterampilan membaca intensif sebagai salah satu aspek keterampilan berbahasa wajib dikuasai dan dimiliki oleh siswa. Hal ini sejalan dengan yang dikemukakan oleh (Dalman, 2014, p. 5) mengatakan bahwa membaca merupakan suatu kegiatan atau proses kognitif yang berupaya untuk menemukan berbagai informasi. Selain itu menurut (Tarigan, 2008, p, 36), “Membaca intensif atau intensive reading adalah studi saksama, telaah teliti, dan penanganan terperinci yang dilaksanakan di dalam kelas terhadap suatu tugas yang pendek kira-kira dua sampai empat halaman setiap hari". Keterampilan membaca intensif yang dimaksud yaitu di kelas rendah yakni di kelas III Sekolah Dasar. Untuk membuat dan mengembangkan bahan ajar cerita dongeng berwawasan nilai-nilai karakter untuk meningkatkan keterampilan membaca intensif diperlukan penilaian ahli terhadap hasil prototype bahan ajar tersebut.

Menurut (Daryanto, 2014, p. 171), "Bahan ajar adalah segala bentuk bahan yang digunakan untuk membantu guru/instruktor dalam melaksanakan kegiatan belajar mengajar di kelas, bahan yang dimaksud bisa berupa bahan tertulis maupun bahan tidak tertulis".Maka bahan ajar dibuat untuk menumbuhkan pembelajaran yang menarik 
dan efektif.

Menurut (Ibnoe, 2016, p. 13), "Mendongeng adalah salah satu metode yang sangat baik untuk meningkatkan kecerdasan anak". Materi-materi yang ada dalam cerita dongeng ini dikembangkan dengan berwawasan nilainilai karakter.

Pendapat tersebut di dukung dengan penelitian (Febriani, 2012,p. 2) yang mengatakan bahwa "Dongeng adalah cerita yang digunakan sebagai metode untuk memperoleh informasi yang merupakan kekayaan budaya bangsa ini, sebelum era masyarakat mengenal tulisan, dongeng merupakan media penanaman nilainilai sosial yang adiluhung oleh para orang tua dan nenek moyang ke generasi penerus."

Menurut (Samani dan Haryanto, 2012, p. 17), "Karakter dimaknai sebagai cara berpikir dan berperilaku yang khas tiap individu untuk hidup dan bekerja sama, baik dalam lingkup keluarga, masyarakat, bangsa, dan negara”. Artinya setiap individu yang berkarakter baik adalah individu yang dapat membuat keputusan dan siap mempertanggungjawabkan setiap akibat dari keputusannya.

Pendapat tersebut didukung dengan pendapat (Asma, 2014, p. 72),"Nilai-nilai karakter adalah nilai agama, norma sosial,peraturan atau hukum, etika akademik, dan prinsip HAM, yang dikelompokkan menjadi lima nilai utama, yaitu nilai-nilai perilaku manusia denganTuhan Yang Maha Esa, diri sendiri, sesama manusia,lingkungan, dan kebangsaan".

Menurut (Dalman, 2014, p. 71) "Membaca intensif pada hakikatnya memerlukan teks yang panjangnya tidak lebih dari 500 kata (yang dapat dibaca dalam jangka waktu 2 menit dengan kecepatan kira-kira 5 kata dalam satu detik)".

Hal ini sependapat dengan (Tarigan, 2008, p. 36), "Membaca intensif atau intensive reading adalah studi saksama, telaah teliti, dan penanganan terperinci yang dilaksanakan di dalam kelas terhadap sutau tugas yang pendek kira-kira dua sampai empat halaman setiap hari”. Dalam pengembangan ini indikator keterampilan membaca intensif yang ringan dan sederhana disesuaikan oleh kebutuhan siswa kelas III Sekolah Dasar yaitu (1) mengenal tokoh cerita dongeng; (2) mengenal latar cerita dongeng; (3) memahami isi cerita dongeng; (4) menemukan amanat/pesan moral dari nilai-nilai karakter dalam cerita dongeng; (5) kemampuan menemukan inti/isi di setiap paragraf cerita dongeng; (6) kemampuan menemukan kesesuaian isi cerita dengan ceria asli; (7) kemampuan menemukan tema/topik cerita dongeng; dan (8) kemampuan menyimpulkan isi cerita dongeng.

Penilaian ahli diperlukan sebagai salah satu acuan dalam menyusun bahan ajar cerita 
dongeng alternatif dengan berwawasan nilainilai karakter yang lebih layak digunakan Sekolah Dasar di Kecamatan Purwodadi Kabupaten Grobogan. Pakar tersebut dilibatkan pada tahap-tahap terakhir kajian. Penilaian kualitas bahan ajar oleh pakar terhadap bahan ajar alternatif yang penyusunannya telah disesuaikan.

Instrumen validasi expert berupa lembar pertanyaan sesuai dengan indikator penilaian dengan pilihan jawaban SK (sangat kurang), K (kurang), B (baik), SB (sangat baik). Selain itu, disediakan lembar yang berisi kolom yang digunakan oleh expert untuk menuliskan bagian yag salah, jenis kesalahan dan masukan untuk perbaikan bahan ajar. Di bagian akhir lembar pertanyaan expert menentukan status kelayakan bahan ajar berdasarkan kriteria: (a) Layak diujicobakan di lapangan tanpa revisi dan (b) Layak diujicobakan di lapangan dengan revisi sesuai saran.

Berdasarkan paparan di atas, dipandang perlu menganalisis penilaian ahli terhadap prototype bahan ajar cerita dongeng berwawasan nilainilai karakter maka peneliti bermaksud mengadakan penelitian yang berjudul “Analisis Penilaian Ahli Terhadap Prototype Bahan Ajar Cerita Dongeng Berwawasan Nilai-Nilai Karakter Siswa Kelas III Sekolah Dasar".
Hasil pengamatan yaitu praktek yang terjadi di lapangan, pembelajaran yang berlangsung di Kecamatan Purwodadi Kabupaten Grobogan ditemukan sedikit bahan ajar cerita dongeng yang berbobot untuk siswa dan guru di masing-masing tingkat satuan pendidikan, karena lokasi menyebabkan kurangnya sumber daya manusia dan guru-guru yang profesional dalam membuat suatu karya bahan ajar khususnya bahan ajar cerita dongeng berwawasan nilai-nilai karakter. Sarana dan prasarana yang tersedia minimal. Selainitu, kegiatan belajar yang menganjurkan pemanfaatan teknologi informasi sebagai media pengajaran masih jarang digunakan. Siswa yang bersekolah rata-rata berasal dari keluarga menengah ke bawah. Untuk membuat dan mengembangkan bahan ajar cerita dongeng berwawasan nilainilai karakter untuk meningkatkan keterampilan membaca intensif yang dibuat hasil karya guru senidir diperlukan penilaian ahli terhadap hasil prototype bahan ajar tersebut.

Maka dari itu penilaian validasi pakar terhadap prototype bertujuan memperoleh masukan, saran, pendapat, komentar sebagai bahan perbaikan dan penyempurnaan sebelum diujicobakan. Konsultasi dengan pakar dilakukan dalam 3 tahap, yakni: (1) menyampaikan konsep prototype yang disusun dan dilampiri lembar validasi; (2) menerima hasil review baik yang berupa komentar, 
masukan, dan saran untuk perbaikan; dan (3) menyampaikan prototype berdasarkan hasil review yang disampaikan ke pakar untuk memperoleh persetujuan pakar.

Berdasarkan paparan masalah yang telah diuraikan di atas, maka rumusan masalah dalam penelitian ini adalah : Bagaimanakah penilaian ahli terhadap prototype bahan ajar ceritadongengberwawasannilai-nilai karakter siswa kelas III Sekolah Dasar berdasarkan analisis penilaian : (1) validasi ahli materi; (2) validasi ahli media; dan (3) validasi ahli bahasa?

\section{METODOLOGI}

Penelitian ini menggunakan metode penelitian kualitatif deskriptif. Teknik pengumpulan data menggunakan teknik wawancara in de depth interview artinya adalah wawancara mendalam mengacu pada (Sugiyono, 2014, p. 137).Teknik pengumpulan data menggunakan wawancara in de depth interview berupa angket berdasarkan analisis penilaian ahli (validasi ahli materi, validasi ahli media, dan validasi ahli bahasa), Adapun tujuan dari penelitian ini adalah memperoleh masukan, saran, pendapat, komentar sebagai bahan perbaikan dan penyempurnaan sebelum diujicobakan.

Penilaian ahli terhadap kelayakan bahan ajar yang ada dalam penelitian ini menggunakan teknik peer-debriefing, yang terutama dilakukan dengan mengadakan wawancara yang lebih mendalam (in-dept interview/ akurat) dengan para kolaborator dan pakar yang terkait dalam menilai layak atau tidaknya bahan ajar.

Penilaian ahli diperlukan sebagai salah satu acuan dalam menyusun bahan ajar cerita dongeng alternatif dengan berwawasan nilainilai karakter yang lebih layak digunakan Sekolah Dasar di Kecamatan Purwodadi Kabupaten Grobogan. Pakar tersebut dilibatkan pada tahap-tahap terakhir kajian. Penilaian kualitas bahan ajar oleh pakar terhadap bahan ajar alternatif yang penyusunannya telah disesuaikan.

Instrumen validasi expert berupa lembar pertanyaan sesuai dengan indikator penilaian dengan pilihan jawaban SK (sangat kurang), K (kurang), B (baik), SB (sangat baik). Selain itu, disediakan lembar yang berisi kolom yang digunakan oleh expert untuk menuliskan bagian yag salah, jenis kesalahan dan masukan untuk perbaikan bahan ajar. Di bagian akhir lembar pertanyaan expert menentukan status kelayakan bahan ajar berdasarkan kriteria: (a) Layak diujicobakan di lapangan tanpa revisi dan (b) Layak diujicobakan di lapangan dengan revisi.

Populasi dalam penelitian ini adalah seluruh pakar/ahli dosen dan guru bidang ahli materi, 
media, dan bahasa. Sampel dalam penelitian ini adalah dosen dan guru pakar ahli bahasa dan media bidang sastra Indonesia Universitas Sebelas Maret Surakarta dan dosen ahli media/desain grafis.

Teknik pengumpulan data pada tahap ini yaitu berupa angket dengan menggunakan teknik wawancara, observasi, dan dokumentasi dalam penelitian ini mengacu pada (Sugiyono, 2015, p.73) tentang langkah-langkah pengumpulan data wawancarayang lebih mendalam (in-dept interview/akurat) menggunakan teknik peerdebriefing. Wawancara mendalam dengan nara sumber. Wawancara difokuskan pada lingkup penilaian ahli/pakar terhadap prototype bahan ajar cerita dongeng berwawasan nilai-nilai karakter yang digunakan oleh siswa kelas III bebrapa Sekolah Dasar Kecamatan Purwodadi Kabupaten Grobogan. Teknik analisis data butir soal menggunakan validitas aiken dan skormenurut panduan penilaian (Sukardjo, 2009, p. 84).

Validasi ahli dilakukan oleh tiga orang Ekspert (Ahli) yaitu ahli media, materi dan bahasa. Tahap ini dilakukan dengan konsultasi dengan menggunakan lembar validasi atau angket penilaian ahli, adapun ahli-ahli tersebut yaitu: (1) validasi ahli materi yang diminta menilai kelayakan materi adalah Prof. St. Y. Slamet, M.Pd seorang guru besar di Universitas Sebelas Maret dan Dwi Sulistyowati, M.Pd seorang guru senior dan kepala sekolah di SD Negeri 6 Purwodadi, Kabupaten Grobogan; (2) validasi ahli media yang diminta untuk menilai tampilan dalam bahan ajar cerita dongeng berwawasan nilai-nilai karakter adalah Dosen Universitas Sebelas Maret Dr. Roemintoyo, M.Pd seorang dosen di Universitas Slamet Riyadi Surakarta dan Nur Badriah, M.Teach seorang guru sekolah dasar senior di SD Negeri 3 Ngraji, Kabupaten Grobogan ; (3) validasi ahli bahasa yang dimintai menilai kelayakan bahasa dalam bahan ajar cerita dongeng berwawasan nilai-nilai karakter adalah Dr. Rukayah, M.Hum dan D Sri Wahyuni, M.Pd; seorang guru senior dan kepala sekolah di SD Negeri 2 Ngembak, Kabupaten Grobogan.

\section{HASIL DAN PEMBAHASAN}

Hasil dalam penelitian ini adalah hasil penilaian ahli terhadap prototype bahan ajar cerita dongeng berwawasan nilai-nilai karakter siswa kelas III Sekolah Dasar layak diujicobakan dengan revisi. Hasil penelitian dan pembahasan dalam penelitian ini dilaporkan dalam Bab IV yang konsisten dengan masalah penelitian yaitu kebutuhan bahan ajar cerita dongeng berwawasan nilainilai karakter untuk meningkatkan keterampilan membaca intensif siswa kelas III Sekolah Dasar berdasarkan analisis penilaian : (1) validasi ahli materi; (2) validasi ahli media; dan (3) validasi ahli 
bahasa.

\section{Ahli Materi}

Prof. Dr. ST Y Slamet, M.Pd, sebagai ahli materi bahasa dam sastra Indonesia pada yang menyampaikan tanggapan penilaian terhadap prototype bahan ajarcerita dongeng berwawasan nilai-nilai karakter siswa kelas III Sekolah dasar yang disusun berdasarkan 6 komponen penilaian yang dikembangkan menjadi 15 komponen indikator penilaian, yakni: (1) judul buku; (2) pengantar buku; (3) Standar Kompetensi, Kompetensi Dasar, dan Indikator; (4) tujuan pembelajaran; (5) petunjuk penggunaan bahan ajar; (6) kegiatan pembelajaran; (7) materi pembelajaran; (8) lembar kerja siswa; (9) lembar evaluasi (Post Test); (10) kunci jawaban lembar evaluasi; (11) petunjuk evaluasi; (12) kesesuaian isi terhadap kondisi siswa daerah kabupaten Grobogan untuk meningkatkan keterampilan membaca intensif; (13) kebenaran substansi; (14) kebermanfaatan dalam pengembanggan pengetahuan berwawasan nilai-nilai karakter untuk meningkatkan keterampilan membaca intensif; (15) kemudahan informasi.

Keenam komponen yang telah lebih spesifik pada bagian materi tersebut dikembangkan dalam instrumen dengan menggunakan pilihan penilaian penskoran dengan skala 1 sampai 5 dengan keterangan 1 sama dengan sangat tidak baik, 2 sama dengan tidak baik, 3 sama dengan cukup, 4 sama dengan baik, dan 5 sama dengan sangat baik dan dilengkapi indikator, dan butir pertanyaan. Butir pertanyaan terdiri dari 30 soal dan diberi skala skor setiap butir pertanyaan. Butir pertanyaan tersebut dapat dipaparkan dan mendapatkan penilaian skor sebagai berikut: (1) kesesuaian judul buku dengan isi buku (Baik); (2) kesesuaian kata pengantar dalam bahan ajar dengan isi bahan ajar (Baik); (3) kejelasan standar kompetensi dalam bahan ajar (Baik); (4) kejelasan kompetensi dasar dalam bahan ajar (Baik); (5) kejelasan rumusan indikator dalam bahan ajar (Cukup); (6) kejelasan tujuan dalam bahan ajar (Cukup); (7) kejelasan petunjuk penggunaan bahan ajar (Cukup); (8) sistematisasi langkahlangkah pembelajaran dalam buku (Baik); (9) kejelasan kegiatan ayo mengamati, ayo bertanya, ayo bacalah, ayo lakukan, ayo berlatih, dan ayo bekerjasama dalam langkahlangkah kegiatan bahan ajar (Cukup); (10) kejelasan langkah-langkah kegiatan pembelajaran dalam meningkatkan pemahaman materi siswa (Cukup); (11) kejelasan langkah-langkah kegiatan pembelajaran dalam meningkatkan hasil belajar siswa aspek sikap, pengetahuan dan keterampilan (Cukup); (12) kesesuaian uraian materi pembelajaran dalam bahan ajar dengan kompetensi dasar (Baik); (13) kesesuaian muatan materi pembelajaran dalam buku dengan kondisi di lingkungan sekitar peserta didik (Baik); (14) kesesuaian muatan Lembar Kerja Siswa (LKS) dalam buku dengan isi buku (Baik); (15) kesesuaian lembar Kerja 
Siswa (LKS) dalam mengembangkan pemahaman siswa (Baik); (16) kesesuaian lembar evaluasi (Posttest) dalam buku dengan isi bahan ajar (Baik); (17) kejelasan skor penilaian lembar evaluasi (posttest) dalam bahan ajar (Baik) (18) kejelasan petunjuk evaluasi dalam bahan ajar (Baik); (19) keterpaduan materi pembelajaran dalam buku (Cukup); (20) kesesuaian isi bahan ajar dalam mengaktifkan siswa (Baik); (21) kesesuaian isi bahan ajar dalam memberikan pengalaman belajar siswa secara langsung (Baik); (22) kesesuaian bahan ajar dalam menyajikan pembelajaran yang menyenangkan bagi siswa (Baik); (23) kesesuaian uraian isi bahan ajar dengan kondisi siswa di daerah Kabupaten Grobogan (Baik); (24) kesesuaian isi bahan ajar dengan tingkat perkembangan siswa (Sangat Baik); (25) kesesuaian isi buku pembelajaran dengan alokasi waktu yang ditentukan (Cukup); (26) kesesuaian isi bahan ajar dalam mengembangkan kemampuan aspek sikap, pengetahuan, dan keterampilan (Baik); (27) ketepatan substansi materi pembelajaran dalam buku (Baik); (28) kebermanfaatan bahan ajar untuk menambah wawasan nilai-nilai karakter yang ditanamkan (Baik); (29) kebermanfaatan bahan ajar dalam meningkatkan keterampilan membaca intensif (Cukup); (30) kemudahan memahami informasi yang disajikan dalam bahan ajar (Baik).
Berdasarkan penilaian ahli terhadap 30 indikator yang telah di paparkan di atas, kesimpulan instrumen validator ahli materi terhadap prototype bahan ajar ini dinyatakan layak digunakan dan diujicobakan setelah selesai revisi sesuai saran.Catatan yang di tulis oleh pakar terhadap bahan ajar cerita dongeng berwawasan nilai-nilai karakter untuk meningkatkan keterampilan membaca intensif dapat di paparkan sebagai berikut: (1) buku siswa tidak perlu mencantumkan kunci jawaban; (2) banyak penulisan kata yang salah ejaan; (3) ada beberapa butir pernyataan yang tidak sesuai; dan (4) bukan "Malin Kundang" tetapi "Malin Kondang".

Dwi Sulistyowati, M.Pd sebagai guru senior dan kepala sekolah yang ahli materi bahasa dan sastra Indonesia pada yang menyampaikan tanggapan penilaian terhadap prototype bahan ajar cerita dongeng berwawasan nilai-nilai karakter siswa kelas III Sekolah dasar yang disusun.Butir pertanyaan terdiri dari 30 soal dan diberi skala skor setiap butir pertanyaan. Butir pertanyaan tersebut dapat dipaparkan dan mendapatkan penilaian skor sebagai berikut: (1) kesesuaian judul buku dengan isi buku (Baik); (2) kesesuaian kata pengantar dalam bahan ajar dengan isi bahan ajar (Baik); (3) kejelasan standar kompetensi dalam bahan ajar (Sangat Baik); (4) kejelasan kompetensi dasar dalam bahan ajar (Baik); (5) kejelasan rumusan indikator dalam bahan ajar (Baik); (6) 
kejelasan tujuan dalam bahan ajar (Sangat Baik); (7) kejelasan petunjuk penggunaan bahan ajar (Cukup); (8) sistematisasi langkahlangkah pembelajaran dalam buku (Sangat Baik); (9) kejelasan kegiatan ayo mengamati, ayo bertanya, ayo bacalah, ayo lakukan, ayo berlatih, dan ayo bekerjasama dalam langkahlangkah kegiatan bahan ajar (Sangat Baik); (10) kejelasan langkah-langkah kegiatan pembelajaran dalam meningkatkan pemahaman materi siswa (Sangat Baik); (11) kejelasan langkah-langkah kegiatan pembelajaran dalam meningkatkan hasil belajar siswa aspek sikap, pengetahuan dan ketrampilan (Sangat Baik); (12) kesesuaian uraian materi pembelajaran dalam bahan ajar dengan kompetensi dasar (Sangat Baik); (13) kesesuaian muatan materi pembelajaran dalam buku dengan kondisi di lingkungan sekitar peserta didik (Baik); (14) kesesuaian muatan Lembar Kerja Siswa (LKS) dalam buku dengan isi buku (Sangat Baik); (15) kesesuaian lembar Kerja Siswa (LKS) dalam mengembangkan pemahaman siswa (Baik); (16) kesesuaian lembar evaluasi (Posttest) dalam buku dengan isi bahan ajar (Sangat Baik); (17) kejelasan skor penilaian lembar evaluasi (posttest) dalam bahan ajar (Baik) (18) kejelasan petunjuk evaluasi dalam bahan ajar (Sangat Baik); (19) keterpaduan materi pembelajaran dalam buku (Sangat Baik); (20) kesesuaian isi bahan ajar dalam mengaktifkan siswa (Sangat Baik); (21) kesesuaian isi bahan ajar dalam memberikan pengalaman belajar siswa secara langsung (Baik); (22) kesesuaian bahan ajar dalam menyajikan pembelajaran yang menyenangkan bagi siswa (Sangat Baik); (23) kesesuaian uraian isi bahan ajar dengan kondisi siswa di daerah Kabupaten Grobogan (Sangat Baik); (24) kesesuaian isi bahan ajar dengan tingkat perkembangan siswa (Sangat Baik); (25) kesesuaian isi buku pembelajaran dengan alokasi waktu yang ditentukan (Sangat Baik); (26) kesesuaian isi bahan ajar dalam mengembangkan kemampuan aspek sikap, pengetahuan, dan keterampilan (Baik); (27) ketepatan substansi materi pembelajaran dalam buku (Sangat Baik); kebermanfaatan bahan ajar untuk menambah wawasan nilai-nilai karakter yang ditanamkan (Sangat Baik); (29) kebermanfaatan bahan ajar dalam meningkatkan keterampilan membaca intensif (Baik); (30) kemudahan memahami informasi yang disajikan dalam bahan ajar (Sangat Baik)

Berdasarkan penilaian ahli terhadap 30 indikator yang telah di paparkan di atas, kesimpulan instrumen validator ahli materi terhadap prototype bahan ajar ini dinyatakan layak digunakan dan diujicobakan setelah selesai revisi sesuai saran.Catatan yang di tulis oleh pakar terhadap bahan ajar cerita dongeng berwawasan nilai-nilai karakter untuk meningkatkan keterampilan membaca intensif dapat di paparkan sebagai berikut: (1) bukunya menarik siswa kelas rendah tetapi jenis materi 
diperbaiki sesuai EYD dan (2) disesuaikan gambar agar siswa lebih tertarik dan fokus.

\section{Ahli Media}

Dr.Roemintoyo, M.Pd, sebagai ahli dalam media dan desain grafis, yang menyampaikan tanggapan penilaian terhadap prototype bahan ajar cerita dongeng berwawasan nilai-nilai karakter siswa kelas III Sekolah dasar yang disusun berdasarkan 8 komponen penilaian yang dikembangkan menjadi 18 komponen indikator penilaian, yakni: (1) kejelasan tujuan; (2) uraian sajian; (3) interaktif; (4) kelengkapan informasi dalam menerapkan pada aspek nilai-nilai karakter yang dikemas dalam bahan ajar; (5) penggunaan huruf; (6) lay out atau tata letak; (7) ilustrasi, gambar atau foto menyajikan aspek nilai-nilai karakter yang dikembangkan dalam bahan ajar untuk meningkatkan keterampilan membaca intensif; (8) desain tampilan.

Kedelapan komponen yang telah lebih spesifik pada bagian desain tersebut dikembangkan dalam instrumen dengan menggunakan pilihan penilaian penskoran dengan skala 1 sampai 5 dengan keterangan 1 sama dengan sangat tidak baik, 2 sama dengan tidak baik, 3 sama dengan cukup, 4 sama dengan baik, dan 5 sama dengan sangat baik. Dan dilengkapi indikator, dan butir pertanyaan. Butir pertanyaan terdiri dari 18 soal dan diberi skala skor setiap butir pertanyaan. Butir pertanyaan tersebut dapat dipaparkan dan mendapatkan penilaian skor sebagai berikut: (1) kejelasan rumusan indikator pembelajaran (Baik); (2) kejelasan rumusan tujuan pembelajaran (Cukup); (3) sistematika sajian seluruh komponen dalam buku pembelajaran (Baik); (4) buku pembelajaran memuat kegiatan yang interaktif (Baik); (5) buku pembelajaran menyajikan informasi yang sesuai dengan tujuan pembelajaran secara lengkap (Baik); (6) kesesuaian informasi dalam buku dengan pembelajaran nilai-nilai karakter (Cukup); (7) kesesuaian informasi dalam buku dengan nilai-nilai karakter yang dikembangkan (Cukup); (8) kesesuaian jenis huruf yang digunakan (Baik); (9) kesesuaian ukuran huruf yang digunakan (Baik); (10) kesesuaian lay out atau tata letak (Baik); (11) keserasian ilustrasi, gambar atau foto (Baik); (12) kesesuaian ilustrasi, gambar atau foto dengan nilai-nilai karakter yang dikembangkan dalam bahan ajar untuk meningkatkan keterampilan membaca intensif yang digunakan (Cukup); (13) kesesuaian ilustrasi, gambar atau foto dalam bahan ajar pembelajaran (Baik); (14) kemenarikan desai sampul (Baik); (15) kesesuaian desain sampul dengan nilai-nilai karakter yang ada (Cukup); (16) keserasian penggunaan komposisi warna (Baik); (17) kemenarikan penggunaan warna (Baik) (18) kesesuaian desain tampilan bahan ajar (Baik). 
Berdasarkan penilaian ahli terhadap 18 indikator yang telah di paparkan di atas, kesimpulan instrumen validator ahli media terhadap prototype bahan ajar ini dinyatakan layak digunakan dan diujicobakan setelah selesai revisi sesuai saran. Catatan yang di tulis oleh pakar terhadap bahan ajar cerita dongeng berwawasan nilai-nilai karakter untuk meningkatkan keterampilan membaca intensif siswa dapat di paparkan sebagai berikut: Bahan ajar tersebut cukup baik dan layak dipakai sebagai suplemen buku ajar.

Nur Badriah, M.Teach, sebagai guru senior dan ahli dalam media dan desain grafis, yang menyampaikan tanggapan penilaian terhadap prototype bahan ajar cerita dongeng berwawasan nilai-nilai karakter siswa kelas III Sekolah dasar yang disusun berdasarkan butir pertanyaan terdiri dari 18 soal dan diberi skala skor setiap butir pertanyaan. Butir pertanyaan tersebut dapat dipaparkan dan mendapatkan penilaian skor sebagai berikut: (1) kejelasan rumusan indikator pembelajaran (Baik); (2) kejelasan rumusan tujuan pembelajaran (Sangat Baik); (3) sistematika sajian seluruh komponen dalam buku pembelajaran (Sangat Baik); (4) buku pembelajaran memuat kegiatan yang interaktif (Sangat Baik); (5) buku pembelajaran menyajikan informasi yang sesuai dengan tujuan pembelajaran secara lengkap (Sangat Baik); (6) kesesuaian informasi dalam buku dengan pembelajaran nilai-nilai karakter (Sangat Baik); (7) kesesuaian informasi dalam buku dengan nilai-nilai karakter yang dikembangkan (Baik); (8) kesesuaian jenis huruf yang digunakan (Sangat Baik); (9) kesesuaian ukuran huruf yang digunakan (Cukup); (10) kesesuaian lay out atau tata letak (Sangat Baik); (11) keserasian ilustrasi, gambar atau foto (Baik); (12) kesesuaian ilustrasi, gambar atau foto dengan nilai-nilai karakter yang dikembangkan dalam bahan ajar untuk meningkatkan keterampilan membaca intensif yang digunakan (Sangat Baik); (13) kesesuaian ilustrasi, gambar atau foto dalam bahan ajar pembelajaran (Sangat Baik); (14) kemenarikan desai sampul (Sangat Baik); (15) kesesuaian desain sampul dengan nilai-nilai karakter yang ada (Baik); (16) keserasian penggunaan komposisi warna (Baik); (17) kemenarikan penggunaan warna (Sangat Baik) (18) kesesuaian desain tampilan bahan ajar (Sangat Baik).

Berdasarkan penilaian ahli terhadap 18 indikator yang telah di paparkan di atas, kesimpulan instrumen validator ahli media terhadap prototype bahan ajar ini dinyatakan layak digunakan dan diujicobakan setelah selesai revisi sesuai saran.Catatan yang di tulis oleh pakar terhadap bahan ajar cerita dongeng berwawasan nilai-nilai karakter untuk meningkatkan keterampilan membaca intensif siswa dapat di paparkan sebagai berikut: (1) jenis ukuran huruf diperbesar untuk siswa kelas rendah dan (2) layout diperhatikan dan 
diperbanyak gambar tetapi buku ini sudah menarik dan bagus.

\section{Ahli Bahasa}

Dr. Rukayah, M. Hum, ahli dalam bahasa dan sastra Indonesia, yang menyampaikan tanggapan penilaian terhadap prototype bahan ajar cerita dongeng berwawasan nilai-nilai karakter siswa kelas III Sekolah dasar yang disusun berdasarkan 5 komponen penilaian yang dikembangkan menjadi 10 komponen indikator penilaian, yakni: (1) kesesuaian dengan EYD; (2) bahasa efektif dan efisien; (3) kesesuaian dengan tingkat perkembangan peserta didik; (4) komunikatif; (5) keruntutan dan kesatuan gagasan.

Kelima komponen yang telah lebih spesifik pada bagian bahasa tersebut dikembangkan dalam instrumen dengan menggunakan pilihan penilaian penskoran dengan skala 1 sampai 5 dengan keterangan 1 sama dengan sangat tidak baik, 2 sama dengan tidak baik, 3 sama dengan cukup, 4 sama dengan baik, dan 5 sama dengan sangat baik dan dilengkapi indikator, dan butir pertanyaan. Butir pertanyaan terdiri dari 10 soal dan diberi skala skor setiap butir pertanyaan. Butir pertanyaan tersebut dapat dipaparkan dan mendapatkan penilaian skor sebagai berikut: (1) kesesuaian bahasa yang digunakan (Baik); (2) keefektifan bahasa yang digunakan (Baik); (3) keefesien bahasa yang digunakan (Baik); (4) kesesuaian dengan tingkat berpikir (Baik); (5) kesesuaian dengan tingkat perkembangan sosial emosional (Baik); (6) keterpahaman pesan (Baik); (7) ketepatan tata bahasa dan ejaan (Baik); (8) kebakuan istilah dan simbol (Baik); (9) keutuhan makna dalam bab, sub-bab,dan paragraf (Baik); (10) ketertautan antar bab, sub-bab, paragraf, dan kalimat (Baik).

Berdasarkan penilaian ahli terhadap 10 indikator yang telah di paparkan di atas, kesimpulan instrumen validator ahli bahasa terhadap prototype bahan ajar ini dinyatakan layak digunakan dan diujicobakan setelah selesai revisi sesuai saran. Catatan yang di tulis oleh pakar terhadap bahan ajar cerita dongeng berwawasan nilai-nilai karakter untuk meningkatkan keterampilan membaca intensif siswa dapat di paparkan sebagai berikut: pendidikan karakternya letakkan di atas.

D Sri Wahyuni, M.Pd, sebagai guru senior dan kepala sekolah yang ahli dalam bahasa dan sastra Indonesia, yang menyampaikan tanggapan penilaian terhadap prototype bahan ajar cerita dongeng berwawasan nilai-nilai karakter siswa kelas III Sekolah dasar yang disusun berdasarkanbutir pertanyaan terdiri dari 10 soal dan diberi skala skor setiap butir pertanyaan. Butir pertanyaan tersebut dapat dipaparkan dan mendapatkan penilaian skor sebagai berikut: (1) kesesuaian bahasa yang digunakan (Sangat Baik); (2) keefektifan bahasa yang digunakan (Sangat Baik); (3) keefesien bahasa yang digunakan (Baik); (4) 
kesesuaian dengan tingkat berpikir (Baik); (5) kesesuaian dengan tingkat perkembangan sosial emosional (Sangat Baik); keterpahaman pesan (Baik); (7) ketepatan tata bahasa dan ejaan (Baik); (8) kebakuan istilah dan simbol (Cukup); (9) keutuhan makna dalam bab, sub-bab,dan paragraf (Sangat Baik); (10) ketertautan antar bab, sub-bab, paragraf, dan kalimat (Sangat Baik).

Berdasarkan penilaian ahli terhadap 10 indikator yang telah di paparkan di atas, kesimpulan instrumen validator ahli bahasa terhadap prototype bahan ajar ini dinyatakan layak digunakan setelah selesai revisi sesuai saran. Catatan yang di tulis oleh pakar terhadap bahan ajar cerita dongeng berwawasan nilainilai karakter untuk meningkatkan keterampilan membaca intensif siswa dapat di paparkan sebagai berikut: (1) perhatikan dan sesuaikan dengan EYD dan (2) buku sudah menrik untuk siswa kelas rendah.

Berdasarkan penjelasan di atas, hasil rekapitulasi validasi dari experts skor menurut panduan penskroran (Sukardjo, 2009, p. 84) diperoleh rekapitulasi hasil validasi ahli materi buku guru oleh Prof. ST Y Slamet, M.Pd rerata yaitu 3,76667 yang berarti tergolong kuallifikasi baik dan Dwi Sulistyowati, M.Pd rerata yaitu 4,7333 yang berarti tergolong kuallifikasi sangat baik. Kemudian hasil validasi ahli materi buku siswa oleh Prof. ST Y Slamet, M.Pd rerata yaitu 3,76667 yang berarti tergolong kuallifikasi baik dan Dwi Sulistyowati, M.Pd rerata yaitu 4,6 yang berarti tergolong kuallifikasi sangat baik. Selanjutnya diperoleh rekapitulasi hasil validasi ahli media buku guru oleh Dr. Roemintoyo M.Pd rerata yaitu 3,72222 yang berarti tergolong kuallifikasi baik dan Nur Badriah, M.Teach rerata yaitu 4,6667 yang berarti tergolong kuallifikasi sangat baik. Kemudian hasil validasi ahli media buku siswa oleh Dr. Roemintoyo M.Pd rerata yaitu 3,72222 yang berarti tergolong kuallifikasi baik dan Nur Badriah, M.Teach rerata yaitu 4,6667 yang berarti tergolong kuallifikasi sangat baik. Selanjutnya diperoleh rekapitulasi hasil validasi ahli bahasa buku guru oleh Dr. Rukayah, M.Pd rerata yaitu 4 yang berarti tergolong kuallifikasi baik dan D Sri Wahyuni, M.Pd rerata yaitu 4,6 yang berarti tergolong kuallifikasi sangat baik. Kemudian diperoleh rekapitulasi hasil validasi ahli bahasa buku siswa oleh Dr. Rukayah, M.Pd rerata yaitu 4 yang berarti tergolong kuallifikasi baik dan D Sri Wahyuni, M.Pd rerata yaitu 4,4 yang berarti tergolong kuallifikasi sangat baik.

Selanjutnya setelah perbaikan buku guru dan siswa dari saran dari expert, butir soal yang berjumlah 25 soal yang akan digunakan untuk mengetahui kemampuan siswa perlu divalidasi oleh 6 expert judgemnets meliputi 3 dosen ahli validasi soal yaitu Dr. Roemintoyo, M.Pd, Ismail S,M.Pd, Dr. Rukayah, M.Hum dan 3 guru ahli validasi soal yaitu D Sriwahyuni, 
M.Pd, Dwi Sulistyowati, M.Pd, dan Nur Badriah, M.Teach menggunakan valisitas aiken mengacu pada (Sugiyono, 2015, p. 72). Berdasarkan hasil perhitungan uji validitas butir soal menggunakan aiken menunjukkan bahwa intrument butir soal yang akan digunakan untuk angket valid semua yaitu $\geq$ 0,79 artinya butir soal no. 1 sampai 25 dinyatakan valid dapat dilihat di lampiran 33 . Kemudian 25 butir soal tersebut akan diujicobakan ke 30 siswa kelas IV yaitu menggunakan aplikasi iteman. Berdasarkan hasil perhitungan uji validitas 25 butir soal ke 30 siswa kelas IV menggunakan iteman menunjukkan bahwa intrument butir soal dari no. 1 sampai 25 dinyatakan valid.

Berdasarkan paparan di atas mengenai penilaian ahli materi, media, dan bahasa terhadap prototype bahan ajar cerita dongeng berwawasan nilai-nilai karakter siswa kelas III Sekolah Dasar dinyatakan bahan ajar ini layak digunakan dan diujicobakan setelah selesai revisi sesuai saran.

\section{KESIMPULAN}

Analisis penilaian ahli terhadap prototype bahan ajarcerita dongeng berwawasan nilainilai karakter siswa kelas III Sekolah dasar dapat diketahui melalui validasi para pakar yang menilai yaitu (a) validasi ahli materi; (b) validasi ahli media; dan (3) validasi ahli bahasa.
Validasi pakar terhadap prototype ajar cerita dongeng berwawasan nilai-nilai karakter bertujuan memperoleh masukan, saran, pendapat, komentar sebagai bahan perbaikan dan penyempurnaan sebelum diujicobakan. Konsultasi dengan pakar dilakukan dalam 3 tahap, yakni: (1) menyampaikan konsep prototype yang disusun dan dilampiri lembar validasi; (2) menerima hasil review baik yang berupa komentar, masukan, dan saran untuk perbaikan; dan (3) menyampaikan prototype berdasarkan hasil reveiw yang disampaikan ke pakar untuk memperoleh persetujuan pakar. Validasi ahli dilakukan oleh tiga orang Ekspert (Ahli) yaitu validasi ahli media, validasi ahli materi dan validasi ahli bahasa.

Hasil penelitian ini menunjukkan bahwa: (1) validasi ahli materi yang diminta menilai kelayakan materi adalah Prof. St. Y. Slamet, M.Pd seorang guru besar di Universitas Negeri Sebelas Maret dan Dwi Sulistyowati, M.Pd seorang guru senior dan kepala sekolah di SD Negeri 6 Purwodadi Kabupaten Grobogan hasilnya adalah bahan ajar layak diujicobakan dengan revisi sesuai saran; (2) validasi ahli media yang diminta untuk menilai tampilan dalam bahan ajar cerita dongeng berwawasan nilai-nilai karakter adalah Dosen Universitas Negeri Sebelas Maret Dr. Roemintoyo, M.Pd dan Nur Badriah, M.Teach seorang guru sekolah dasar senior di SD Negeri 3 Ngraji, 
Kabupaten Grobogan hasilnya adalah bahan ajar layak diujicobakan dengan revisi sesuai saran; (3) validasi ahli bahasa yang dimintai menilai kelayakan bahasa dalam bahan ajar cerita dongeng berwawasan nilai-nilai karakter adalah Dr. Rukayah, M.Hum dan D Sri Wahyuni, M.Pd; seorang guru senior dan kepala sekolah di SD Negeri 2 Ngembak Kabupaten Grobogan hasilnya adalah bahan ajar layak diujicobakan dengan revisi sesuai saran.

Berdasarkan hasil perhitungan uji validitas butir soal menggunakan aiken menunjukkan bahwa intrument butir soal yang akan digunakan untuk angket valid semua yaitu $\geq$ 0,79 artinya butir soal no. 1 sampai 25 dinyatakan valid dapat dilihat di lampiran 33. Kemudian 25 butir soal tersebut akan diujicobakan ke 30 siswa kelas IV yaitu menggunakan aplikasi iteman. Berdasarkan hasil perhitungan uji validitas 25 butir soal ke 30 siswa kelas IV menggunakan iteman menunjukkan bahwa intrument butir soal dari no. 1 sampai 25 dinyatakan valid.

\section{SARAN}

Agar pembelajaran lebih bermakna, saran diajukan kepada: (a) guru, yaitu perlu membuat karya sendiri bahan ajar khsusunya cerita dongeng berwawasan nilai-nilai karakter siswa kelas III Sekolah Dasar sehingga dapat menyusun bahan ajar yang memiliki pendekatan yang sesuai dengan kemampuan ; (b) siswa, yaitu dengan adanya bahan ajar karya guru yang berkualitas setelah divalidasi oleh para pakar siswa dapat termotivasi untuk aktif dalam kegiatan pembelajaran sehingga pembelajaran menjadi lebih menarik dan bermakna bagi siswa; (c) peneliti, yaitu mengembangkan keterampilan membuat bahan ajar hasil karya sendiri khususnya bahan ajar bahasa Indonesia keterampilan membaca intensif cerita dongeng dengan lebih kreatif dan inovatif; (d) pengambil kebijakan, yakni pemerintah daerah khususnya dinas pendidikan Kabupaten Grobogan untuk dapat menyediakan anggaran untuk memfasilitasi sarana dan prasarana yang diperlukan guru untuk pengembangan bahan ajar dan pembuatan bahan ajar hasil karya guru sendiri tanpa harus menunggu mendapatkan dari penerbit..

\section{DAFTAR PUSTAKA}

Asma, Jamal Mamur. (2014). Buku Panduan Internalisasi Pendidikan Karakter di Sekolah Dasar. Yogyakarta: Diva Press.

Dalman. (2014). Keterampilan Membaca. Jakarta: Raja Grafindo Persada.

Daryanto. (2014). Pengembangan Perangkat Pembelajaran (Silabus, RPP, PHB, Bahan Ajar). Yogyakarta: Gaya Media.

Febriani, Meina. (2012). Pengembangan Bahan Ajar Apresiasi Dongeng 
Banyumasbagi Siswa SD Kelas

Rendah.Jurnal Pendidikan Bahasa

dan Sastra, 1 (6), 1-8.

Ibnoe. (2016). Mari Mendongeng.

Yogyakarta: Zora Book.

Mardiah, dkk. (2016). Pengembangan Modul

Membaca Intensif Materi Cerita

Petualangan Berbasis Intensif.Jurnal

Penelitian dan Pengembangan, 1 (1),

1115-1119.

Mustari. (2014). Nilai karakter untuk Refleksi

Pendidikan. Jakarta: Raja Grafindo

Persada.

Samani dan Hariyanto. (2012). Konsep dan

Model Pendidikan Karakter.

Bandung: Rineka Cipta.

Sugiyono. (2014). Metodologi Penelitian

Kuantitatif, Kualitatif dan kombinasi

(Mixed Method). Bandung: Alfabeta.

Sukardjo M. (2009). Landasan Pendidikan

Konsep Dan Aplikasinya. Jakarta:

Rajawali Pers.

Tarigan. (2008). Membaca sebagai suatu

Keterampilan Berbahasa. Bandung:

Angkasa.

Ulum, Wisda Miftakul. (2014).

Pengembangan Pengembangan Buku

Teks Membaca Intensif Berbasis

Karakter di Sekolah Dasar. Junal

Penidikan Humaniora, 2 (2), 130-

143. 